\title{
Disseminated cutaneous sporotrichosis in a patient with AIDS: Report of a case
}

\author{
Esporotricose cutânea disseminada em paciente \\ com AIDS: Relato de um caso
}

\author{
Miriam Tomoko Mitsuno Carvalho', Adriana Pinheiro de Castro1, Cristiane Baby', \\ Betina Werner ${ }^{2}$, José Filus Neto ${ }^{2}$ and Flávio Queiroz-Telles ${ }^{1}$
}

\begin{abstract}
We describe a case report of disseminated cutaneous sporotrichosis as the initial presentation of AIDS in a 24-year-old HIV-positive male patient. He presented multiple ulcerated skin lesions distributed over the face, thorax, legs and arms. Biopsy of one of the cutaneous lesions was suggestive of sporotrichosis and culture isolated Sporothrix schenckii. Itraconazole was started and the lesions progressively resolved after 15 days of medication. The patient was discharged with this medication but he did not return for follow-up. He died three months later in another hospital. Therapy of sporotrichosis in HIV-infected patients remains unclear and the response to therapy is variable. Itraconazole is highly concentrated in the skin and is one of the options for treatment of disseminated sporotrichosis.
\end{abstract}

Key-words: Sporotrichosis. AIDS. Sporothrix schenkii. Itraconazole.

Resumo Descrevemos um relato de caso de esporotricose cutânea disseminada como apresentação inicial de AIDS em um paciente masculino de 24 anos HIV positivo. Ele apresentava múltiplas lesões cutâneas ulceradas, distribuídas na face, tórax, pernas e braços. A biopsia de uma das lesões cutâneas foi sugestiva de esporotricose e a cultura revelou Sporothrix schenckii. Foi iniciado o tratamento com itraconazol e as lesões progressivamente involuiram depois de 15 dias de medicação. O paciente teve alta com tratamento ambulatorial, mas não retornou para seguimento. Ele morreu três meses depois em outro hospital. O tratamento da esporotricose em pacientes HIV positivos ainda não está estabelecido. Por sua boa penetração cutânea, 0 itraconazol é uma das melhores opções para formas disseminadas de esporotricose.

Palavras-chaves: Esporotricose. SIDA. Spotothrix schenkii. Itraconazol.

Sporotrichosis is caused by Sporothrix schenkii, a saprobic dimorphic fungus found in soil, vegetation, rotting wood, animal excreta and sphagnum moss. It has a worldwide distribution, but it is found mainly in temperate and tropical areas. Some occupations can predispose individuals to infection, such as gardening, masonry and floral work ${ }^{10}$.

The infection is usually limited to the cutaneous and subcutaneous tissues most frequently as a consequence of a traumatic implantation of the etiologic agent onto the $\operatorname{skin}^{21013}$. Occasionally, inhalation of conidia may occur and cause pulmonary and disseminated infection ${ }^{257}$.

The most common clinical presentation of sporotrichosis is lymphocutaneous (Table 1), where a primary lesion develops at the site of inoculation and may progress with nodular lesions along the lymphatic distribution proximal to the initial lesion ${ }^{271013}$. Males and females, usually under 30 years of age, are equally affected $^{10}$. The clinical manifestations and radiographic findings of pulmonary sporotrichosis are similar to those of pulmonary tuberculosis and affects middle-aged men generally with chronic obstructive pulmonary disease and alcoholism?.

Immunologically intact patients may have hematogenous dissemination and develop osteoarticular lesions ${ }^{10}$. However, immunosuppression such as alcoholism, diabetes, chronic obstructive pulmonary disease, malignancies, transplantation, corticosteroid therapy and those infected with HIV increases the probability of disseminated disease ${ }^{110}$.

\footnotetext{
1. Infectious Diseases Division. 2. Medical Pathology Division of Hospital de Clínicas of Federal University of Paraná, Curitiba, PR, Brazil. Address to: Dr. Flavio de Queiroz Telles Filho. R. Capitão Souza Franco 529/07. 80730-420 Curitiba, PR. Brazil

e-mail: queiroz.telles@netpar.com.br

Recebido para publicação em 15/10/2001.
} 
Table 1 - Clinical forms of sporotrichosis.

\begin{tabular}{ll}
\hline Forms & Manifestations \\
Cutaneous & Fixed (verrucous, ulcerated, plaque like, disseminated, others) \\
Lymphocutaneous & Ascendant, abscessed lymphangitis \\
Extracutaneous & Pulmonary \\
& Osteoarticular \\
& Neurologic \\
& Disseminated \\
\hline
\end{tabular}

Fungal infections are among the most common infectious complications in HIV-infected patients ${ }^{13}$, however, disseminated sporotrichosis rarely occurs ${ }^{5}$. The dissemination generally affects skin but other organs such as joints, lung, liver, spleen, intestine and meninges can also be involved in HIV-patients ${ }^{6}$. Research for dissemination must be considered in HIV-patients with lymphocutaneous sporotrichosis.

This article presents a case report of disseminated cutaneous sporotrichosis as the initial presentation of AIDS.

\section{CASE REPORT}

A 24-year-old male, gardener, presented at our service, in November 2000, for evaluation of multiple cutaneous lesions of three months duration, which initially involved the left leg, and spread to face, thorax and arms. Ten days prior to the presentation he had been admitted to another hospital for evaluation of fever and jaundice, and also during this admission HIV infection had been diagnosed. He had a history of syphilis, heavy consumption of alcohol and intravenous drug use.

Physical examination revealed multiple ulcerated painful lesions of many sizes, with raised, indurated margins, and a yellow fetid secretion, distributed over the face, thorax, arms and legs (Figure 1). The results of laboratory investigations included positive Anti-HCV, negative serologic tests for hepatitis $A, B$, leptospirosis and syphilis, normal serum transaminase activities, bilirubin and creatinine, alkaline phosphatase 175UI/L, hemoglobin $10.4 \mathrm{mg} / \mathrm{dl}$, hematocrit $30.5 \%$, white blood cell count 7500 cells $/ \mathrm{mm}^{3}$ and $16 \%$ band forms, CD4 count 62 cells $/ \mathrm{mm}^{3}$. He had a normal radiography of the thorax and as the patient did not present with any other evidence of disease no further investigation was performed.

The secondary bacterial infection was treated with cefazolin and amikacin. A biopsy of one of the lesions of the right anterior trunk was performed and revealed numerous oval and cigar-shaped conidia, suggesting sporotrichosis (Figure 2). A few days later, culture of the skin biopsy isolated Sporothrix schenkii. Itraconazole was started (200mg daily) and the skin lesions progressively resolved after 15 days of medication.

Therapy with zidovudine, didanosine and indinavir was started and also prophylaxis for pulmonary pneumocystosis with thrimethoprim-sulphamethoxazole. The patient was discharged with these medications and although instructed to return for follow-up he did not. Three months later, the patient was admitted to another hospital with multiple organ failure, acute respiratory failure, cardiac arrest and death. No autopsy examination was performed.

\section{DISCUSSION}

Since 1983, 43 cases of cutaneous sporotrichosis have already been diagnosed by culture at the Laboratory of Mycology from Hospital de Clínicas in Curitiba, however this was the first case of association with AIDS.

Although HIV-infected patients may develop potentially life-threatening disseminated fungal infections, sporotrichosis is encountered relatively infrequently ${ }^{12}$ and is very difficult to eradicate with the applied treatment ${ }^{589}$.

To date, a number of cases with various clinical presentations have been reported, with predominance of disseminated cutaneous forms similar to this case. Al-Tawfiq et al reviewed the reported cases until 1997 and found 17 cases of Sporotrichosis occurring in HIVinfected patients. All of them presented with diffuse ulcerated skin lesions, involvement of the CNS in four cases, ocular involvement in two cases, articulations in four cases, spleen in one case, sinusitis in one case and bone marrow in one case ${ }^{1}$. Since 1997, four cases have been reported, all of them with disseminated cutaneous involvement ${ }^{3}{ }^{11} 12$ and two of them with osteoarticular involvement ${ }^{312}$ (Table 2).

In this case, considering that the patient was a gardener, it is possible that he was infected by accidental inoculation of the fungus as usually occurs. On the other hand our patient did not present pulmonary involvement and the hematogenous dissemination was not really explained.

Because the clinical features of sporotrichosis in patients with AIDS may be very different from those seen in immunocompetent hosts, biopsy and culture of skin lesions should always be performed in order to make an early diagnosis and initiate appropriate treatment ${ }^{12}$. Differential diagnosis of lymphocutaneous form of 

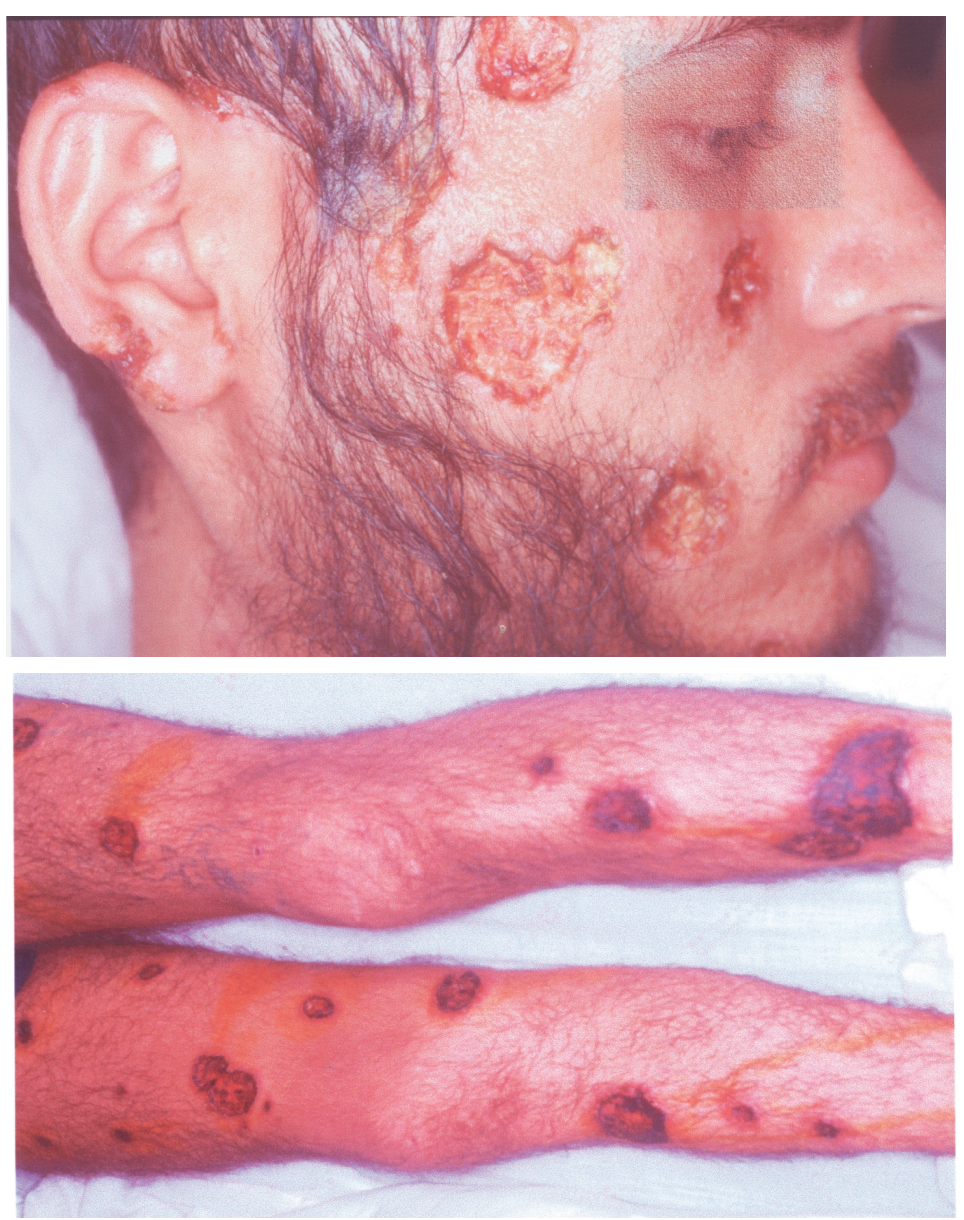

Figure 1 - Disseminated cutaneous sporotrichosis in AIDS patient.

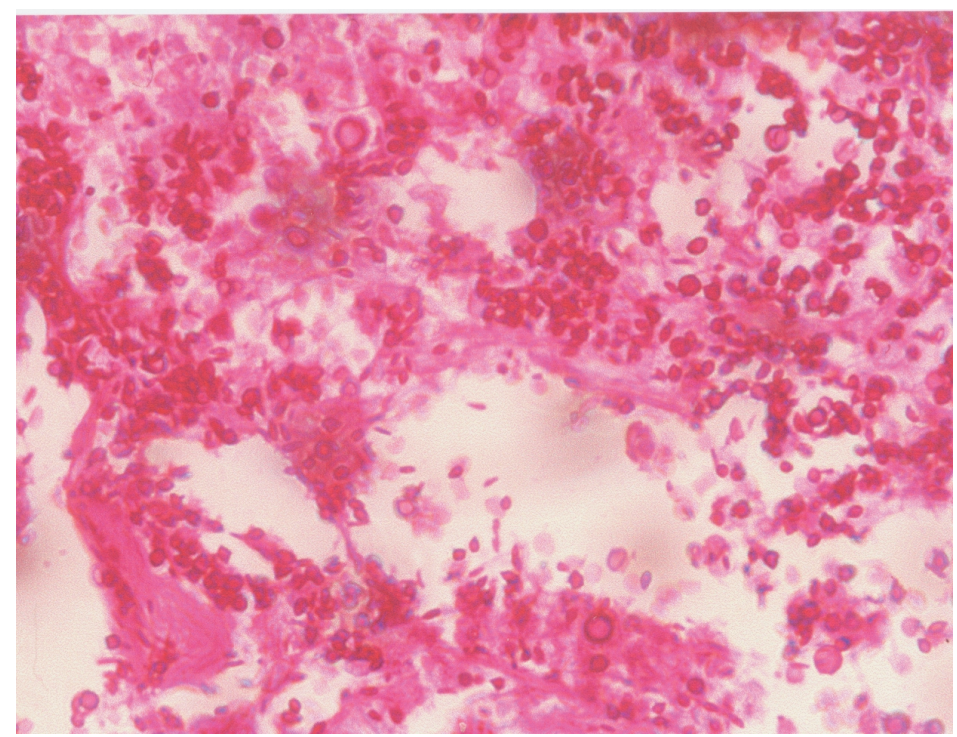

Figure 2 - Skin section. Several round to elongated yeast Sporothrix schenkii yeast cells. PAS, $X 1,000$. 
Table 2 - Summary of data from reported cases of sporotrichosis in HIV-infected patients

\begin{tabular}{|c|c|c|c|c|c|c|}
\hline Clinical presentation & age/sex & $\mathrm{CD} 4\left(\mathrm{cells} / \mathrm{mm}^{3}\right)$ & $\begin{array}{l}\text { Initial culture } \\
\text { positive sites }\end{array}$ & Initial therapy & Outcome & Ref \\
\hline skin lesions, arthritis & $34 / \mathrm{M}$ & NR & $\begin{array}{l}\text { skin, synovial } \\
\text { fluid }\end{array}$ & $\mathrm{AmB}+5-\mathrm{FC}$ & ag. isolated at autopsy & 6 \\
\hline skin lesions & $31 / \mathrm{M}$ & 58 & none & Itra & complete response & 6 \\
\hline skin lesions, arthritis, cough & $71 / \mathrm{F}$ & 140 & skin & $A m B$ & complete response & 6 \\
\hline skin lesions, uveitis & $30 / M$ & NR & skin & $A m B$ & progression & 6 \\
\hline skin lesions & $43 / \mathrm{M}$ & NR & Skin, sputum & $A m B$ & partial response & 6 \\
\hline skin lesions, arthritis & $30 / \mathrm{M}$ & NR & $\begin{array}{l}\text { Skin, synovial } \\
\text { fluid }\end{array}$ & SSKI & partial response & 6 \\
\hline skin lesions & $49 / M$ & 11 & $\begin{array}{l}\text { skin, sputum, } \\
\text { blood, BM }\end{array}$ & $\mathrm{AmB}+5-\mathrm{FC}$ & progression, death & 6 \\
\hline \multirow[t]{2}{*}{ skin lesions } & $41 / \mathrm{M}$ & NR & skin & $A m B$ & response after & \\
\hline & & & & & initial relapse & 6 \\
\hline skin lesions & $38 / \mathrm{M}$ & NR & synovial fluid & Itra & complete response & 6 \\
\hline skin lesions & $43 / \mathrm{M}$ & 56 & skin, & AmB & death & 6 \\
\hline skin lesions & $22 / M$ & 17 & skin, & Flu & death & 6 \\
\hline skin lesions & $30 / \mathrm{M}$ & 63 & skin, sputum & Ket & death & 6 \\
\hline skin lesions, cough & $37 / \mathrm{M}$ & 345 & sputum & NR & NR & 6 \\
\hline skin lesions, sinusitis & $49 / \mathrm{M}$ & 19 & sinus biopsy & Itra & complete response & 6 \\
\hline skin lesions & $32 / \mathrm{M}$ & 10 & skin, & AmB & death & 6 \\
\hline skin lesions & $33 / \mathrm{M}$ & NR & skin, lymph node & NR & NR & 6 \\
\hline skin lesions & $47 / \mathrm{M}$ & 9 & skin, blood & $A m B+I t r a$ & complete response & 6 \\
\hline \multirow[t]{3}{*}{ skin lesions, arthritis } & $42 / M$ & 10 & synovial fluid, & $A m B+$ Itra & recurrence with & \\
\hline & & & & & discontinuation & 8 \\
\hline & & & blood & & & \\
\hline skin lesions & $34 / \mathrm{F}$ & 104 & skin & AmB+ltra & death & 10 \\
\hline skin lesions & $30 / \mathrm{M}$ & 81 & skin & $A m B$ & complete response & 11 \\
\hline skin lesions, arthritis & $43 / \mathrm{M}$ & NR & $\begin{array}{l}\text { skin, synovial } \\
\text { fluid, blood }\end{array}$ & $A m B$ & complete response & 12 \\
\hline skin lesions & $24 / M$ & 62 & skin & Itra & $\begin{array}{l}\text { complete } \\
\text { response }\end{array}$ & $\begin{array}{r}\text { Present } \\
\text { report }\end{array}$ \\
\hline
\end{tabular}

Note: $\mathrm{AmB}=$ amphotericin $\mathrm{B}$, Itra = itraconazole, Flu = fluconazole, Ket = ketoconazole, NR = not reported, SSKI = saturated solution of potassium iodide, $5-F C=5$-fluorocytosine, $B M=$ bone marrow

sporotrichosis include fungal diseases (paracoccidioidomycosis, chromoblastomycosis), mycobacterial infections, syphilis, nocardiosis, and noninfectious diseases as basocellular carcinoma and sarcoidosis ${ }^{7}$.

The histopathologic findings of sporotrichosis in HIVpatients are also unusual, because the inflammatory reaction is reduced and the number of microorganisms may be very large $\mathrm{e}^{12}$. S. schenkii is difficult to detect in histologic sections from immunocompetent patients and cultures are more likely to establish the diagnosis ${ }^{3}$. The biopsy of this patient revealed a great number of oval, cigar-shaped yeasts, consistent with S. schenkil ${ }^{457}$, which contributed to establish the diagnosis which was confirmed by culture.

Therapy for sporotrichosis in immunocompetent hosts is well established. Itraconazole is the drug of choice for cutaneous, lymphocutaneous and osteoarticular sporotrichosis. While amphotericin B is required for severe pulmonary infection and disseminated sporotrichosis ${ }^{8}$. On the other hand, therapy for disseminated sporotrichosis in HIV-infected patients remains unclear and the response to therapy is variable ${ }^{1}$. The classic therapy with potassium iodine, successfully used to treat the cutaneous and lymphocutaneous forms in immunocompetent patients is not recommended for use in HIV-infected patients or other conditions associated with immunodeficiency ${ }^{11}$.

On the basis of the favorable response in cases reported, amphotericin B and itraconazole seem to be reasonable choices for initial therapy of sporotrichosis in HIV-patients ${ }^{1}$. Amphotericin B has been the treatment of choice for disseminated disease, however its dose is limited by nephrotoxicity and it is being replaced by the use of azole antifungal agents ${ }^{812}$. Itraconazole is highly concentrated in the skin and is generally more effective in the treatment of cutaneous fungal infections than fluconazole ${ }^{12}$. Itraconazole was used as initial therapy in 3 of 21 cases reported, and the response was optimal ${ }^{1}$. The cutaneous lesions from the present case had a good response to itraconazole. Therapeutic failures have been described in association with potassium iodine, fluconazole and ketoconazole ${ }^{1}$. 
Liposomal amphotericin B has been recently used for fungal infections when there is any kind of intolerance to the conventional amphotericin $\mathrm{B}^{11}$. Neto et al had good results with this drug in the treatment of disseminated cutaneous sporotrichosis associated with AIDS ${ }^{11}$. Ware et al also used liposomal amphotericin B resulting in progressive resolution of the cutaneous lesions but with recurrence of the lesions after discontinuation of amphotericin and despite oral administration of itraconazole, fluconazole and terbinafine ${ }^{12}$.

For patients who have both HIV infection and sporotrichosis, lifelong maintenance therapy is recommended and itraconazole is the drug of choice ${ }^{178}$. Five patients receiving itraconazole had no evidence of recurrence of the lesions after 9-12 months ${ }^{1}$. Maintenance therapy with fluconazole for previous cryptococcal meningitis was not sufficient to avoid sporotrichosis in a patient with AIDS, and Goldani et al suggest that the therapeutic failure associated with itraconazole could be explained by a possible crossresistance to azoles ${ }^{4}$. In the present case, it was not possible to evaluate the response to the maintenance therapy with itraconazole since the patient failed to return for follow-up and died due to unconfirmed causes.

\section{REFERENCES}

1. Al-Tawfiq JA, Wools KK. Disseminated Sporotrichosis and Sporothrix schenckii Fungemia as the Initial Presentation of Human Immunodeficiency Virus Infection. Clinical Infectious Diseases 26: 1403-1406,1998.

2. Davis BA. Sporotrichosis. Dermatologic Clinics 14:69-76, 1996.

3. Edwards C, Reuther WL $3^{\text {rd }}$, Greer DL. Disseminated osteoarticular sporotrichosis: treatment in a patient with acute AIDS syndrome. Southern Medical Journal 93: 803-806, 2000.

4. Goldani LZ, Aquino VR, Dargel AA. Disseminated Cutaneous Sporotrichosis in an AIDS Patient Receiving Maintenance Therapy with Fluconazole for Previous Cryptococcal Meningitis. Clinical Infectious Diseases 28:1337-1338,1999.

5. Gori S,Lupetti A, Moscato G, Parenti M, Lofaro A. Pulmonary Sporotrichosis with Hyphae in a Human Immunodeficiency VirusInfected Patient. Acta Cytologica 41: 519-521,1997.

6. Johnson RA. HIV Disease: Mucocutaneous Fungal Infections in HIV disease. Clinics in Dermatology 18: 411-422,2000.

7. Kauffman CA. Sporotrichosis. Clinical Infectious Diseases 29: 231-237,1999.
8. Kauffman CA, Hajjeh R, Chapman SW. Practice Guidelines for the Management of Patients with Sporotrichosis. Clinical Infectious Diseases 30:684-687,2000.

9. Keiser P, Whittle D. Sporotrichosis in Human Immunodeficiency Virus-Infected Patients: Report of a case. Reviews of Infectious Diseases 13: 1028-1029,1991.

10. Kwong-Chung KJ, Bennet JE. Sporotrichosis. In: Kwong-Chung KJ, Bennet JE (ed) Medical Mycology, Philadelphia: Lea \& Febiger p.707-729,1992.

11. Neto RD, Machado AA, de Castro G, Quaglio AS, Martinez R. Acquired immunodeficiency syndrome presenting as disseminated cutaneous sporotrichosis- case report. Revista da Sociedade Brasileira de Medicina Tropical 32:57-61,1999.

12. Ware AJ, Cockerell CJ, Skiest DJ, Kussman HM. Disseminated sporotrichosis with extensive cutaneous involvement in a patient with AIDS. Journal of the American Academy of Dermatology 40:350-355, 1999.

13. Warnock DW, Richardson MD. Fungal infection in the Compromised Patient. John Wiley \& Sons 39: 274-278,1991. 